\title{
"The impact of cash flow statement components on stock volatility: Evidence from Qatar"
}

\begin{tabular}{|c|c|c|}
\hline AUTHORS & Othman Hel Al-Dhaimesh (iD) & Mo’taz Kamel Al Zobi (D) \\
\hline ARTICLE INFO & \multicolumn{2}{|c|}{$\begin{array}{l}\text { Mo'taz Kamel Al Zobi and Othman Hel Al-Dhaimesh (2021). The impact of cash } \\
\text { flow statement components on stock volatility: Evidence from Qatar. Investment } \\
\text { Management and Financial Innovations, 18(2), 365-373. } \\
\text { doi:10.21511/imfi.18(2).2021.29 }\end{array}$} \\
\hline DOI & \multicolumn{2}{|c|}{ http://dx.doi.org/10.21511/imfi.18(2).2021.29 } \\
\hline RELEASED ON & \multicolumn{2}{|l|}{ Monday, 28 June 2021} \\
\hline RECEIVED ON & \multicolumn{2}{|l|}{ Sunday, 30 May 2021} \\
\hline ACCEPTED ON & \multicolumn{2}{|l|}{ Friday, 25 June 2021} \\
\hline LICENSE & \multicolumn{2}{|c|}{$\begin{array}{l}\text { This work is licensed under a Creative Commons Attribution } 4.0 \text { International } \\
\text { License }\end{array}$} \\
\hline JOURNAL & \multicolumn{2}{|c|}{ "Investment Management and Financial Innovations" } \\
\hline ISSN PRINT & \multicolumn{2}{|l|}{$1810-4967$} \\
\hline ISSN ONLINE & \multicolumn{2}{|l|}{$1812-9358$} \\
\hline PUBLISHER & \multicolumn{2}{|c|}{ LLC "Consulting Publishing Company "Business Perspectives" } \\
\hline FOUNDER & \multicolumn{2}{|c|}{ LLC "Consulting Publishing Company "Business Perspectives" } \\
\hline$\sigma^{0}$ & 15 & $\begin{array}{l}\text { 三E: } \\
\Xi \Xi\end{array}$ \\
\hline NUMBER OF REFERENCES & NUMBER OF FIGURES & NUMBER OF TABLES \\
\hline 19 & 5 & 4 \\
\hline
\end{tabular}

(c) The author(s) 2021. This publication is an open access article. 


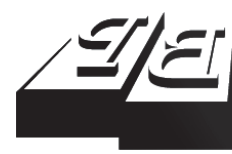

BUSINESS PERSPECTIVES

(O)

LLC "CPC "Business Perspectives" Hryhorii Skovoroda lane, 10, Sumy, 40022, Ukraine www.businessperspectives.org
Received on: $30^{\text {th }}$ of May, 2021 Accepted on: $25^{\text {th }}$ of June, 2021 Published on: $28^{\text {th }}$ of June, 2021

(c) Mo’taz Kamel Al Zobi, Othman Hel Al-Dhaimesh, 2021

Mo’taz Kamel Al Zobi, Assistant Professor, Accounting Department, Business Faculty, Amman Arab University, Amman, Jordan. (Corresponding author)

Othman Hel Al-Dhaimesh, Assistant Professor, Accounting Department, Ahmed Bin Mohammed Military College, Doha, Qatar.

\title{
THE IMPACT OF CASH FLOW STATEMENT COMPONENTS ON STOCKS VOLATILITY: EVIDENCE FROM QATAR
}

\begin{abstract}
The published financial statements are considered one of the most important sources of information that investors rely on in forecasting stock performance or even judging the organization's ability to cover short-run liabilities. Cash flows play a core role in maintaining a high market value for its shares. Hence, this study came to analyze the explanatory value of the cash flow statement in explaining stock volatility (SV) in the Qatar financial market. Study data were collected using published financial statements from a sample of 44 Qatari-listed companies throughout 2013-2019. A panel cross-sectional data technique using the E-views program was used to analyze the data. The study results show there is a positive and significant impact of cash flows from operating $\mathrm{CFO}$ activities on SV, indicating that the higher change in CFO increases stock volatility. This means that operating cash flows give significant information to investors, and it is reflected in the stock price movements directly. Also, the cash flow from CFF financing activities has a positive and significant effect on SV. This means that CFF affects stock prices, causing greater changes and fluctuation in stock returns. This is because one of the major components of CFF is dividends, which affect directly stock prices and stock returns. In contrast, there is an insignificant effect of CFI on SV, which may indicate that investors do not build their investment decisions based on CFI. Accordingly, the cash flow from investing activities failed to explain the stock volatility of the listed Qatari companies.
\end{abstract}

\section{Keywords}

JEL Classification

\section{INTRODUCTION}

Financial statements are considered one of the most important sources of information in the financial market. The accounting information depends on it for securities evaluation purposes, which enables interested parties to make a comparison between different investment opportunities in the financial market (Deaconu \& Nistor, 2009). There is no doubt that the quality and quantity of accounting information helps stakeholders and other interested parties in the financial market to forecast share performance (Franczak, 2019). Fama (1970) argued that an efficient market should reflect the true value of stocks at all times and for all parties. The existence of inefficient financial markets leads to the occurrence of the problem of information asymmetry, meaning that some dealers or large investors possess information that small investors do not possess, or the lack of information or unjust availability of information to all dealers in the financial market. Some investors' feeling of unequal access to information regarding particular security is sufficient to lead to the reluctance of investors to deal in it, which leads to a decrease in the volume of financial transactions in the market, which turns the stock market into a market for random speculation, thus shadowing decision-makers. 
There is no doubt that the efficiency of financial markets depends mainly on the informational content of financial reports, which, in turn, reflect the real share prices (Dang et al., 2017). Usually, financial statements are prepared according to the accrual or cash basis, and the main difference between them is the point revenue and expense recognition. It is also known that the income statement and the statement of financial position are prepared based on an accrual basis. In contrast, the statement of cash flow is prepared based on a cash accounting basis. Many investors suffered heavy losses in their investments in joint-stock companies such as W.T Grant Co., which declared its bankruptcy in 1974, although the income and financial position statements were showing high net income and retained earnings.

The question that arises is why these companies went bankrupt, despite the fact that their financial reports gave positive indicators. The reason is the inability of the companies to generate cash flows to cover their liabilities, even though they have positive net income and retained earnings. Besides, relying on the accounting profit and the financial position prepared based on accrual basis only without relying on the cash flows prepared based on cash basis leads to wrong investment decisions, especially in predicting stock performance. Based on the above, the problem of the study is crystallized in that relying only on net income or the financial position statement items based on accrual bases in explaining the share performance is insufficient and may lead to the bankruptcy of a company and shadows current and potential investors in some way. Accordingly, this study aimed to analyze the explanatory value of cash flows from operating, investing, and financing activities in relation to stock volatility.

\section{LITERATURE REVIEW}

Since the development of financial markets in the 1920 s to the end of the 1970 s, reliance was mainly on the financial statements prepared on an accrual basis in forecasting share performance such as the income statement and changes in financial position. However, this interest began to wane after many companies went bankrupt, although financial statements show positive performance. Biswas et al. (2015) believe that financial statements based on an accrual basis provide an opportunity to manipulate and inflate profits by exploiting available accounting methods and methods to influence share prices to attract more investors. For example, a company can manipulate depreciation calculation methods to reduce taxes payable, delay recognition of some expenses, or accelerate the recognition of some revenues, thus maximizing net income and the market value of shares in a fictitious way.

Professional bodies around the world have realized the importance of cash flow statements. In 1987, the FAS issued a statement of Financial Accounting Standards No. (95) in which required companies to prepare a statement of cash flows instead of a list of changes in equity. In this context, in 1992, the International Accounting Standards Committee issued the revised International
Standard No. (7) titled "Statement of Cash Flows" to be a substitute for the "Statement of Owner's Equity" issued in 1977, in which it emphasized the need to prepare the statement of cash flows as a supplement to other financial statements, with the aim of providing information on the operating, investment and financing activities of a unit based on a cash basis. The statement of cash flows provides useful information to users of the output of an accounting system about cash receipts and payments during a given period. In this regard, International Standard No. (7) requires companies to classify their cash flows into three sections such as operating, investing, and financing cash flows.

Many studies have revealed that the statement of cash flows has great importance for decision-makers, in that it provides information that the income statement and financial position do not provide, as it is a reflection of the market value of the facility (Kasmiati \& Santosa, 2019). Khaled (2012) conducted a study on Jordanian commercial banks and concluded that the statement of cash flow significantly affects share value. Also, cash flow from operating activities was the strongest impact. In this context, Gunanta et al. (2015) concluded that the statement of cash flow information and EPS have a positive effect on stock prices of listed Indonesian manufacturing companies. Musah 
and Kon (2019) state that there is a significant and positive relationship between cash flows and ROA, whereas, an insignificant and positive relationship is found between cash flows and ROE of firms listed on Ghana Stock Exchange.

The first section is cash flows from CFO operating activities; the continuity of companies depends primarily on the existence of positive operating cash flows sufficient to cover their obligations such as loans, capital expenditures, taxes, and the distribution of dividends. Nazemi and Abdoli (2015) believe that the presence of high cash flows from operating activities is an indicator of judging the quality of a company's liquidity and profitability. In the same way, Utomo and Pamungkas (2018) found that cash flows from operating activities positively affected stock returns of listed Indonesian firms. Also, Soet et al. (2018) concluded that the operating cash flow positively affects ROA and ROE in Kenya. Whereas Dang et al. (2018) found a significant impact of EPS, stock B.V, cash flowi from operating activities, and firm size on stock prices of Vietnamese listed firms. Oroud et al. (2017) pointed out that $13.27 \%$ of changes in share prices was explained by cash flow information. Also, increasing the cash flow from operating activities increases the share price. In the same context, Alslehat and Al-Nimer (2017) found that the cash flow from operating and investing has a strong and positive relationship with financial performance. Also, Ikechukwu et al. (2015) found the cash flow from operating and financing activities positively affects return on total assets (ROTA) in the Nigerian banking sector. In contrast, Nazemi and Abdoli (2015) pointed out that cash flows from operating activities have a direct and negative association with EPS.

The second section of a cash flow statement is cash flows from investment activities CF. This type of cash flows is related to the acquisition or disposal of long-term assets and investments in equity and debt instruments such as stocks bonds. This type of cash flow gives an indication of the possible future contraction of a company. High cash flows from investing activities indicate that the company disposed of its long-term assets or other investments. Quite the opposite, lower cash flows of this type indicate an increase in growth and profits. In contrast, Utomo and Pamungkas
(2018) found out that cash flows from investment negatively affect stock returns of listed Indonesian firms. Also, Oroud et al. (2017) concluded that an increase in the cash flow from financing and investing activities leads to a decrease in the share prices of Jordanian listed firms.

The third section of the statement of cash flows is cash flows from financing activities CFF. This type of flow shows a company's financing policy for its equity or loan needs, as well as the composition of the capital structure. Typically, these types of flows are financed by the owners of an enterprise through paid-in capital, loans, creditors, and other short-term lending instruments. Nangih et al. (2020) concluded that only cash from financing activities has a positive relationship with financial performance of oil and gas companies in Nigeria. In the same way, Utomo and Pamungkas, (2018) found that the cash flows from financing activities positively affected stock returns of listed Indonesian firms. Also, Oroud et al. (2017) concluded that increasing the cash flow from financing and investing activities leads to a decrease in the share prices of Jordanian listed firms. In contrast, Alslehat and Al-Nimer (2017) pointed out there is a weak and negative relationship between cash flows from financing activities and financial performance of Jordanian insurance companies.

\section{STUDY CONTRIBUTION}

A cash flow statement is considered one of the most important financial statements in that it shows the monetary impact of all activities carried out by a company during the financial period. It also helps investors in predicting future cash flows and their ability to pay short-term liabilities. Accordingly, this study attempts to analyze the explanatory value of cash flows from operating, investment, and financing activities on the stock volatility of the listed Qatari companies. Besides, through a survey of previous studies conducted on this topic, it was found that there is a scarcity of previous studies that have investigated this topic from the practical side, which necessitated the need to test the explanatory power of cash flow statements on stock volatility, which adds research value to what the studies dealt with. 


\section{METHODOLOGY}

This study aims to test the explanatory value of a cash flow statement to explain stock volatility of listed Qatari companies from 2013 to 2019). To measure this effect, data on cash flows from operating, investing, and financing activities were collected. After data was collected, a panel cross-sectional data technique using the E-views program was used to analyze the study data.

\subsection{Study variables}

Table 1 explains study variables and provides measurements.

Table 1. Study variables and measurement

\begin{tabular}{|c|c|c|}
\hline Variables & Indicators & Measurement \\
\hline \multirow{3}{*}{$\begin{array}{l}\text { Independent } \\
\text { variable }\end{array}$} & $\begin{array}{l}\text { Cash flow from } \\
\text { operating activities } \\
\text { (CFOA) }\end{array}$ & $\begin{array}{l}\triangle \mathrm{CFOA}=(\text { Current CFOA }- \\
\text { Last CFOA/Last. CFOA }) \times 100\end{array}$ \\
\hline & $\begin{array}{l}\text { Cash flow from } \\
\text { investing activities } \\
(\mathrm{CFIA})\end{array}$ & $\begin{array}{l}\triangle \mathrm{CFIA}=(\text { Current } \mathrm{CFIA}-\text { Last } \\
\mathrm{CFIA} / \text { Last } \mathrm{CFIA}) \times 100\end{array}$ \\
\hline & $\begin{array}{l}\text { Cash flow from } \\
\text { financing activities } \\
\text { (CFFA) }\end{array}$ & $\begin{array}{l}\triangle \mathrm{CFFA}=(\text { Current } \mathrm{CFFA}-\text { Last } \\
\text { CFFA/Last CFFA }) \times 100\end{array}$ \\
\hline $\begin{array}{l}\text { Dependent } \\
\text { variable }\end{array}$ & Stock Volatility (SV) & $\begin{array}{l}\text { SV }=\text { the annual standard } \\
\text { deviation of daily stock } \\
\text { return } \\
\text { Daily Stock return }(S R)= \\
\text { (Current } S R-\text { Last } S R / \text { Last } \\
\text { SR) } \times 100\end{array}$ \\
\hline $\begin{array}{l}\text { Control } \\
\text { variable }\end{array}$ & Net Income (NI) & $\begin{array}{l}\Delta \mathrm{NI}=(\text { Current NI }- \text { Last NI/ } \\
\text { Last NI) } \times 100\end{array}$ \\
\hline
\end{tabular}

\subsection{Study models}

To analyze the effect of a statement of cash flows on stock volatility, the following multiple linear regression model was used:

$$
\begin{aligned}
& S V_{i t}=\alpha+\beta 1 C F O_{i, t}+\beta 2 C I A_{i, t}+ \\
& +\beta 3 C F F_{i, t}+\beta 4 N I_{i, t}+\varepsilon,
\end{aligned}
$$

where $S V$ - stock volatility, $C F O$ - cash flows from operating activities, CIA - cash flows from investing activities, $C F F$ - cash flows from financing activities, and $\mathrm{NI}$ - net income.

\subsection{Study hypotheses}

This study is based on the following main hypothesis:
$H_{0.1}: \quad$ The cash flow statement does not affect stock volatility of listed Qatari companies.

The derived sub-hypotheses are as follows:

$H_{0.1 .1}:$ The cash flow from operating activities does not affect stock volatility of the listed Qatari companies.

$H_{0.12}:$ The cash flow from investing activities does not affect stock volatility of the listed Qatari companies.

$H_{0.13}:$ The cash flow from financing activities does not affect stock volatility of the listed Qatari companies.

\section{HYPOTHESIS TESTING RESULTS}

\subsection{Descriptive statistics}

Table 2 summarizes the descriptive statistics of the study variables. Based on Table 2, the average stock volatility (SV) of the sample companies during the period 2013 to 2019 , measured by the standard deviation of the daily stock return, was about $3 \%$, which is a relatively small value and thus reflects small variability in stock returns. This finding reflects the low risk embedded in stocks of Qatari public companies. The SV value ranged from $0.19 \%$ to $7.05 \%$, with a standard deviation of $1.63 \%$, which indicates the variation in SV from year to year and from a company to another.

The average of cash flows from operating activities (CFO), measured by the annual change in CFO, reached $-16.5 \%$, reflecting the decreasing cash transaction over time and more reliance on noncash transactions. CFO ranged from $-875.2 \%$ to $856.3 \%$, with a standard deviation of $175.8 \%$. This indicates a significant variation in operating cash flows from one company to another and over the years of the study. This huge volatility in operating cash flows may indicate weak management of the Qatar public companies' cash flows.

The average cash flows from investing activities (CFI), measured by the annual change in CFI, 
reached $-28.2 \%$, which may indicate the heavy investment of those companies over time. CFI ranged from $-934.5 \%$ to $865 \%$, with a standard deviation of $214 \%$. This indicates a significant variation in cash flows from investing from a company to another and over the years of the study. This huge volatility in cash flows from investing activities may also reflect the expansion trend and growth of Qatari public companies overtime.

The third component of the cash flow, namely, cash flows from financing activities (CFF), measured by the annual change in CFF, reached on average $-20.9 \%$, which may indicate that companies have a heavy dividend policy, and they tend to repay loans. CFF ranged from $-748 \%$ to $670 \%$, with a standard deviation of $188.5 \%$. This indicates a significant variation in cash flows from financing from a company to another and over the years of the study. This huge volatility in cash flows from financing activities may also reflect that Qatari public companies rely more on internal financing over time rather than loans.

Finally, net income (NI), measured by the annual change in NI, reached $0.86 \%$, which indicates the companies' ability to sustain positive profitability over time. However, NI ranged from $-491 \%$ to $522.6 \%$, with a standard deviation of $79.3 \%$, which indicates a significant variation in companies' earnings from a company to another and over the years of the study.

Figure 1 shows time-series trends of SV (dependent variable) from 2013 to 2019. Based on Figure 1 , the average value of stock volatility witnessed a modest change during the study period. SV ranged from $2.5 \%$ to $3.5 \%$, indicating the relative stability of stock returns during the study period.

Figure 2 shows the time-series trend of CFO (cash flows from operating activities) from 2013 to 2019. The annual average of CFO, measured by the annual change in CFO, witnessed dramatic fluctuation during the study period, with a general downward trend. This may reflect the weak management of cash flows from operation activities in Qatari public companies.

Figure 3 shows the time-series trend of CFI (cash flows from investing) from 2013 to 2019 . The annual average of CFI, measured by the annual change in CFI, witnessed a dramatic decline since 2014.

Table 2. Descriptive statistics of the study variables

\begin{tabular}{|c|c|c|c|c|c|}
\hline & SV & CFO & CFI & CFF & NI \\
\hline Mean & 3.020 & -16.492 & -28.200 & -20.881 & 0.861 \\
\hline Median & 2.966 & -11.230 & -31.630 & -13.820 & 1.118 \\
\hline Maximum & 7.048 & 856.324 & 864.976 & 670.183 & 522.586 \\
\hline Minimum & 0.194 & -875.228 & -934.450 & -748.038 & -491.400 \\
\hline Std. Dev. & 1.630 & 175.853 & 214.036 & 188.464 & 79.323 \\
\hline Skewness & 0.332 & 0.403 & 0.528 & -0.127 & -0.4962 \\
\hline Kurtosis & 3.066 & 7.912 & 5.405 & 6.020 & 3.1289 \\
\hline Jarque-Bera & 5.009 & 64.848 & 63.281 & 58.250 & 5.6792 \\
\hline Probability & 0.0817 & 0.0000 & 0.000 & 0.000 & 0.0594 \\
\hline Observations & 308 & 308 & 308 & 308 & 308 \\
\hline Cross sections & 44 & 44 & 44 & 44 & 44 \\
\hline
\end{tabular}

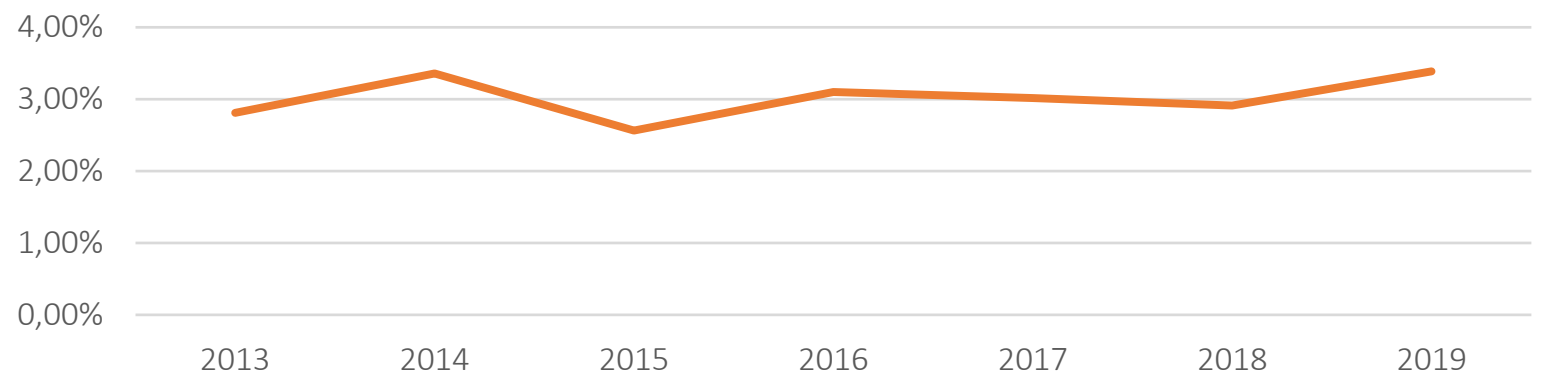

Figure 1. Stock volatility (SV) (2013-2019) 


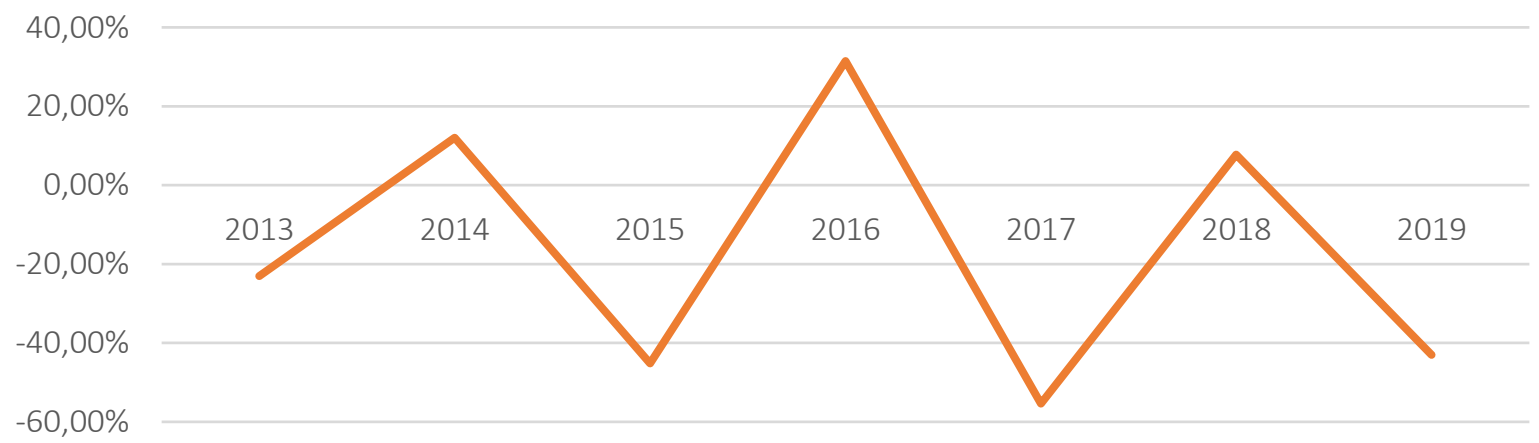

Figure 2. Cash flows from operations (CFO) (2013-2019)

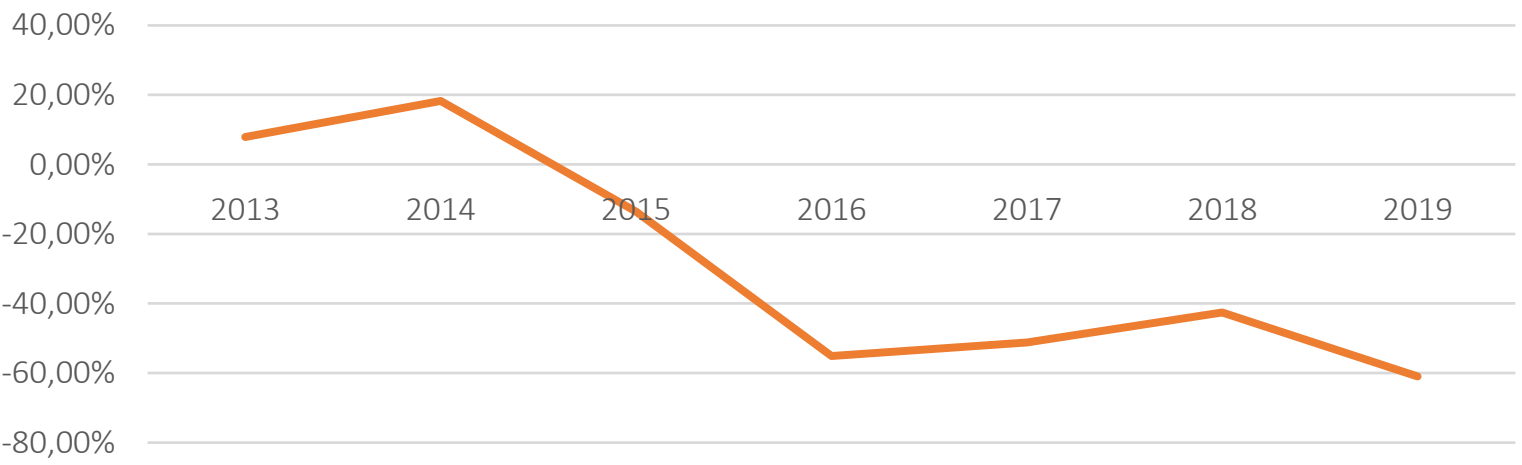

Figure 3. Cash flows from investment (CFI) (2013-2019)

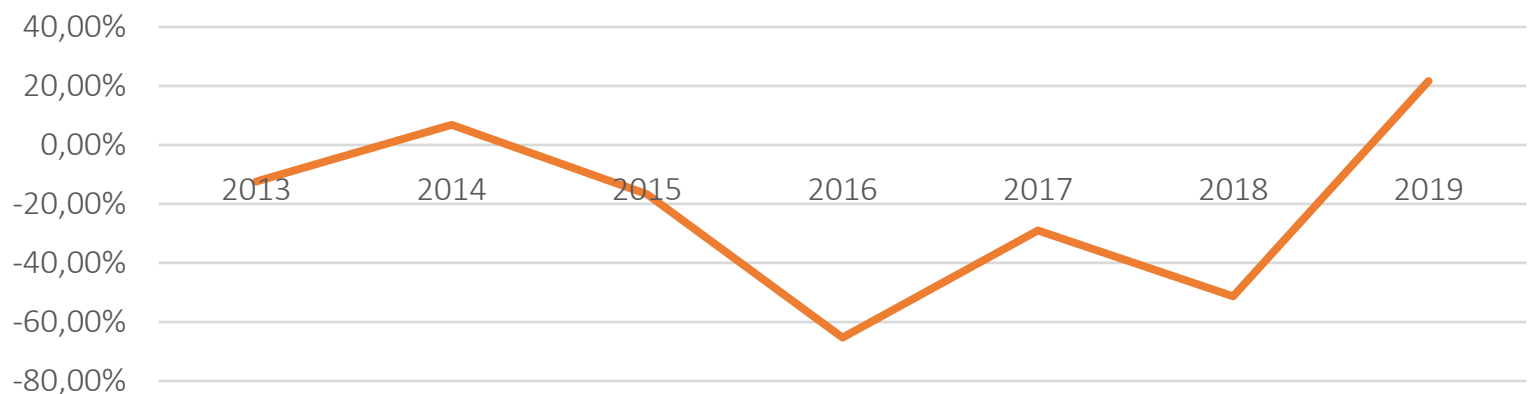

Figure 4. Cash flows from financing (CFF) (2013-2019)

This may reflect the heavy investment of Qatari public companies over time.

Figure 4 shows the time-series trend of CFF (cash flows from financing) from 2013 to 2019. The annual average of CFF, measured by the annual change in CFF, witnessed a dramatic decline during 2014-2018, which may indicate the companies have a heavy dividend policy and tend to repay loans during that period.

Finally, Figure 5 shows the time-series trend of net income (NI). The annual average of NI, measured by the annual change in NI, witnessed a high increase in 2014, followed by a high decline in 2015 and 2016, then it starts to increase gradually in 2017 and 2019.

Table 3 shows the Pearson correlation matrix for the dependent and independent variables. The table indicates a positive correlation between SV and $\mathrm{CFO}, \mathrm{CFI}$, and NI, while there is a negative correlation between SV and CFF. However, the correlations among independent variables are relatively low, indicating the absence of multi-collinearity.

\subsection{Regression analysis results}

Table 4 shows panel data regression results of the study model, which tests the effect of CFO, CFI, CFF, 


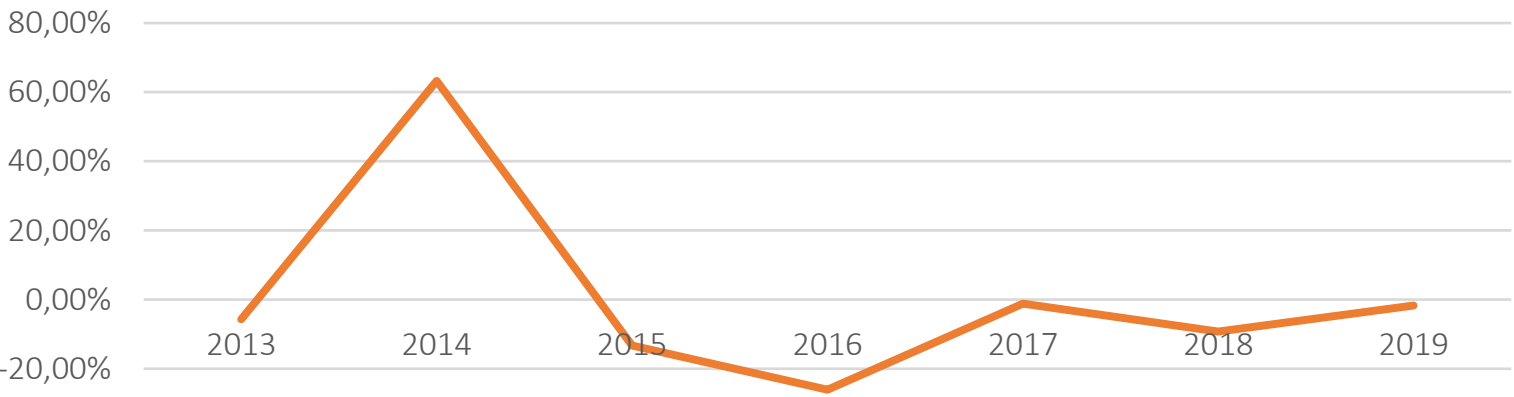

$-40,00 \%$

Figure 5. Net income (NI) (2013-2019)

Table 3. Pearson correlation matrix

\begin{tabular}{l|c|c|c|c|c}
\hline & SV & CFO & CFI & CFF & NI \\
\hline SV & 1.0000 & & & \\
CFO & 0.1962 & 1.0000 & & \\
CFI & -0.0602 & 0.1376 & 1.0000 & 1.0000 \\
CFF & 0.1303 & 0.0898 & 0.0031 & -0.1360 & 1.0000 \\
\hline NI & 0.1824 & -0.1246 & 0.1010 & \\
\hline
\end{tabular}

and NI on stock volatility (SV). Panel data regression method was used as it fits the study data, which includes 44 Qatari companies over a 7-year period (2013 - 2019). Moreover, a generalized least square (GLS) estimation method will be used to capture the differences among cross-sections (companies).

According to Table 4, the CFO coefficient was positive and significant, indicating that the higher change in CFO increases stock volatility. This result is consistent with the expected and with the findings of other researchers, who found that operating cash flows give significant information to investors, and it is reflected in the movements in stock prices, causing greater changes and fluctuation in stock returns. Thus, cash flows from operating activities can explain the stock volatility of listed Qatari companies.

The CFI coefficient was insignificant, indicating that the change in CFI has no effect on stock volatility. This result does not meet the expectations of this study and the findings of other researchers, since the change in CFI should give investors important information about investment activities of companies, their current capital expenditures, the potential expansion of a company in the future. However, the insignificant effect of CFI on SV may indicate that investors do not build their investment decisions based on CFI. Accordingly, cash flows from investing activities failed to explain stock volatility of the listed Qatari companies.
The coefficient of CFF was positive and significant, indicating that the higher change in CFF causes higher stock volatility. This result is consistent with the expectations of this study and with the findings of other researchers, who found that cash flows from financing activities affect stock prices, causing greater changes and fluctuation in stock returns. This is because one of the major components of CFI is dividends, which affect directly stock price and stock return, and stock returns. Thus, cash flows from financing activities can explain the stock volatility of listed Qatari companies.

Finally, the coefficient of NI was positive and significant, indicating that higher changes in net income cause higher stock volatility. This result is consistent with the expectation of this study and with the findings of other researchers, because the higher change in net income affects stock prices directly through EPS, causing greater changes and fluctuations in stock returns in response to the change in NI. Thus, net income can explain the stock volatility of listed Qatari companies.

Based on the above, it can be concluded that the study found evidence in the Qatar financial market that companies are successfully managing their cash flows and play a fundamental role in maintaining the high market value of their shares. 
Table 4. Regression analysis results of the study model

\begin{tabular}{|c|c|c|c|}
\hline Variable & Coefficient & T-statistic & Prob. \\
\hline C & 0.9362 & 6.6715 & 0.0000 \\
\hline CFO & 0.4457 & 2.9692 & 0.0036 \\
\hline $\mathrm{CFI}$ & -0.0111 & -0.6001 & 0.5489 \\
\hline CFF & 0.0526 & 2.0701 & 0.0407 \\
\hline $\mathrm{NI}$ & 0.0269 & 3.4787 & 0.0006 \\
\hline \multicolumn{4}{|c|}{ Regression statistics } \\
\hline Dependent variable & \multicolumn{3}{|c|}{ SV } \\
\hline Method & \multicolumn{3}{|c|}{ Pooled EGLS (Cross-section weights) } \\
\hline Included observations & \multicolumn{3}{|c|}{7} \\
\hline Cross-sections included & \multicolumn{3}{|c|}{44} \\
\hline Total pool (balanced) observations & \multicolumn{3}{|c|}{308} \\
\hline$R$-squared & \multicolumn{3}{|c|}{0.4942} \\
\hline Adjusted $R$-squared & \multicolumn{3}{|c|}{0.4797} \\
\hline S.e. of regression & \multicolumn{3}{|c|}{1.2069} \\
\hline Durbin-Watson stat & \multicolumn{3}{|c|}{1.8918} \\
\hline F-statistic & \multicolumn{3}{|c|}{5.3019} \\
\hline Prob. (F-statistic) & \multicolumn{3}{|c|}{0.0004} \\
\hline
\end{tabular}

Note: $*$ White standard errors and covariance (d.f. corrected).

\section{CONCLUSION}

The study concluded that there is a positive and significant effect of cash flows from CFO operating activities, indicating that the higher change in CFO increases stock volatility. This means that operating cash flows give significant information to investors, and it is reflected in stock price movements directly. Also, cash flows from CFF financing activities have a positive and significant effect on SV. This means that CFF affects stock prices, causing greater changes and fluctuations in stock returns. This is because dividends are one of the major components of CFF that directly affect stock prices and stock returns. In contrast, CFI has an insignificant impact on SV, which may indicate that investors are not basing their investment decisions on CFI. Accordingly, the cash flow from investing activities failed to explain the stock volatility of listed Qatari companies.

\section{AUTHOR CONTRIBUTIONS}

Conceptualization: Mo'taz Kamel Al Zobi, Othman Hel Al-Dhaimesh.

Data curation: Mo'taz Kamel Al Zobi, Othman Hel Al-Dhaimesh.

Formal analysis: Mo'taz Kamel Al Zobi, Othman Hel Al-Dhaimesh.

Funding acquisition: Mo'taz Kamel Al Zobi, Othman Hel Al-Dhaimesh.

Methodology: Mo'taz Kamel Al Zobi, Othman Hel Al-Dhaimesh.

Software: Mo’taz Kamel Al Zobi, Othman Hel Al-Dhaimesh.

Supervision: Mo'taz Kamel Al Zobi, Othman Hel Al-Dhaimesh.

Validation: Mo'taz Kamel Al Zobi, Othman Hel Al-Dhaimesh.

Writing - original draft: Mo’taz Kamel Al Zobi, Othman Hel Al-Dhaimesh.

Writing - review \& editing: Mo'taz Kamel Al Zobi, Othman Hel Al-Dhaimesh. 


\section{REFERENCES}

1. Alslehat, Nimer \& Al-Nimer, Munther (2017). Empirical Study of the Relationship between Cash Flow Management and Financial Performance of the Jordanian Insurance Companies. International Business Management, 11(3), 776782. Retrieved from http://dx.doi. org/10.36478/ibm.2017.776.782

2. Cable, R., Healy, P., \& Li, C. (2017). Assessing the Impact on Cash Flows from Operating Activities - FASB's Proposed Accounting Standards Update. The Journal of Global Business Management, 12(1), 1-7. Retrieved from http://www.jgbm. org/page/1\%20Roberta\%20Cable. pdf

3. Dang, N., Hoang, T., \& Tran, M. (2017). The Relationship Between Accounting Information in the Financial Statements and the Stock Returns of Listed Firms in Vietnam Stock Exchange. International Journal of Economics and Finance, 9(10), 1-10. https://doi.org/10.5539/ ijef.v9n10p1

4. Dang, N., Tran, M., \& Nguyen, T. (2018). Investigation of The Impact of Financial Information on Stock Prices: The Case of Vietnam. Academy of Accounting and Financial Studies Journal, 22(2), 1-12. Retrieved from https://www. abacademies.org/articles/investigation-of-the-impact-of-financialinformation-on-stock-prices-thecase-of-vietnam-7223.html

5. Fama, E. (1970). Efficient Capital Markets: A Review of Theory and Empirical Work. The Journal of Finance, 25(2), 383-417. https://doi. org $/ 10.2307 / 2325486$

6. Franczak, I. (2019). The relations between the quality of financial statements and corporate governance. International Journal of Management and Economics, 55(2), 118-126. https://doi.org/10.2478/ ijme-2019-0009

7. Gunanta, R., Sherlita, E, \& Lestari, S. (2015). The effects of the statement of cash flows and earning per share (EPS) on stock prices: Empirical study on manufacturing industry in Indonesia. International Conference on Accounting Studies, 522-527.
Retrieved from https://core.ac.uk/ download/pdf/42984301.pdf

8. Ikechukwu, O., Nwakaego, D., \& Celestine, A. (2015). The Effect of Cash Flow Statement on Companies Profitability (A Study of Some Selected Banks in Nigeria). African Journal of Basic \& Applied Sciences, 7(6), 350-356. https://doi.org/10.5829/idosi. ajbas.2015.7.6.1156

9. Kanani, A., Mirniya, S., Farajzadeh, A., \& Aboutalebzadeh, S. (2014). The relation between changes of cash flow statement's components and market value of accepted companies in Tehran stock exchange. Indian Journal of Fundamental and Applied Life Sciences, 4(1), 1807-1812. Retrieved from https://www.cibtech.org/sp.ed/ jls/2014/01/204-000\%20(32).pdf

10. Kasmiati, \& Santosa (2019). The effect of earning information, cash flow components, and financing decision on stock returns: empirical evidence on Indonesia stock exchange. Journal of Economics, Business, and Accountancy Ventura, 22(2), 157-166. Retrieved from https://journal.perbanas.ac.id/index. php/jebav/article/view/1638

11. Khaled, M. (2012). Financial Crisis, Cash Flows, and Market Value per share in the Jordanian Commercial Banks for the Period 2000-2009. Interdisciplinary Journal of Contemporary Research in Business, 4(8), 191-201.

12. Khanji, I., \& Siam, A. (2015). The Effect of Cash Flow on Share Price of the Jordanian Commercial Banks Listed in Amman Stock Exchange. International Journal of Economics and Finance, 7(5). https://doi. org/10.5539/ijef.v7n5p109

13. Musah, M., \& Kong, Y. (2019). The affiliation between cash flows and the financial performance of non-financial firms: an empirical evidence from the Ghana stock exchange (GSE). EPRA International Journal of Research and Development (IJRD), 4(4), 84-92.
14. Nangih, E., Ofor, T., \& Ven, O. (2020). Cash Flow Management and Financial Performance of Quoted Oil and Gas Firms in Nigeria. Journal of Accounting and Financial Management, 6(4), 1-11. Retrieved from https://iiardpub.org/get/JAFM/ VOL.\%206\%20NO.\%204\%202020/ Cash\%20Flow\%20Management\%20 and\%20Financial.pdf

15. Nazemi, H., \& Abdoli, M. (2015). The Relationship of Stock Return with Earnings and Cash Flows before and after Financial Statement Restatements by the Companies Listed on the Tehran Stock Exchange. European Online Journal of Natural and Social Sciences, 4(1), 75-79. Retrieved from https:// www.sid.ir/en/journal/ViewPaper. aspx?id $=653184$

16. Oroud, Y., Islam, M., \& T. A, T. (2017). The Effect of Cash Flows on the Share Price on Amman Stock Exchange. American Based Research Journal, 6(7), 22-28.

17. Percy, W., \& P. G., M. (2015). Cash Flows and Firm Performance: Some Evidence from the Sri Lankan Firms Cash Flow. Journal of Management Matters, 2(1), 41-48. https://doi. org/10.2139/ssrn.2795323

18. Soet, M., Muturi, W., \& Oluoch, O. (2018). Effect of operating cash flow management on financial performance of mutual funds in Kenya. European Journal of Business, Economics and Accountancy, 6(5), 37-46. Retrieved from http://www. idpublications.org/wp-content/ uploads/2018/10/Full-PaperEFFECT-OF-FINANCING-CASHFLOW-MANAGEMENT-ON-FINANCIAL-PERFORMANCE-OFMUTUAL-FUNDS-IN-KENYA.pdf

19. Utomo, D., \& Pamungkas, I. (2018). Cash flow activities and stock returns in manufacturing of indonesia: a moderating role of earning management. Academy of Accounting and Financial Studies Journal, 22(6), 1-10. Retrieved from https://www.abacademies.org/ articles/cash-flow-activities-andstock-returns-in-manufacturingof-indonesia-a-moderating-role-ofearning-management-7688.html 